\title{
PENYULUHAN TENTANG TATA CARA MEMBUAT PERATURAN PERUSAHAAN DI PT. PELANGI WARNA KREASI BANDUNG
}

\author{
Ahmad Hunaeni Zulkarnaen \\ Pascasariana Program Magister Ilmu Hukum dan Fakultas Hukum \\ Universitas Suryakancana \\ E-mail: ahmadz@gmail.com
}

\begin{tabular}{|l|l|l} 
Masuk : Maret 2017 & Penerimaan : Maret 2017 & Publikasi : Juni 2017
\end{tabular}

\begin{abstract}
ABSTRAK
Pengusaha yang mempekerjakan pekerja/buruh sekurang-kurangnya 10 (sepuluh) orang wajib membuat peraturan perusahaan. Peraturan perusahaan adalah peraturan yang dibuat secara tertulis oleh pengusaha yang memuat syarat-syarat kerja dan tata tertib perusahaan. Di dalam pembuatan peraturan perusahaan perlu secara berkesinambungan dilakukan bimbingan teknis supaya terwujud peraturan perusahaan yang memberikan perlindungan bagi pekerja. Pembuatan peraturan perusahaan merupakan tanggung jawab pengusaha, yang dalam proses pembuatannya harus memperhatikan saran dan pertimbangan dari wakil pekeria atau dari serikat pekerja/buruh.
\end{abstract}

Kata Kunci: Peraturan; Perusahaan; Penyuluhan; dan Karyawan.

\section{ABSTRACT}

Employers who hire at least 10 (ten) employees shall make a company regulation. A company regulation is a written rule made by the employer which contains the terms of employment and the rules of the company. In the rule-making companies need continually to do under the technical guidance in order to gain the company rules that provide a protection for workers. Rule-making company is the employers' responsibility, which is in the drafting process should heed the advice and judgment of representatives of workers or from labor unions.

Keywords: Regulation, Company, Extension, and Employee.

\section{A. PENDAHULUAN}

1. Latar Belakang

Dalam rangka memberikan kepastian atas hak dan kewajiban antara pengusaha dan pekerja/buruh di perusahaan diperlukan pedoman yang jelas dan tertulis dalam bentuk Peraturan Perusahaan. Peraturan Perusahaan yang telah dibuat oleh perusahaan wajib mendapat pengesahan dari Menteri atau Pejabat yang ditunjuk, sehingga dapat menjadi pedoman dalam pelaksanaan hubungan kineria di perusahaan. Peraturan perusahaan yang telah mendapat pengesahan wajib dibagikan kepada semua pekerja agar para pekerja mengetahui hak dan kewajibannya dalam hubungan kerja. Peraturan perusahaan merupakan sarana pengaturan syarat yang dinamis, karena hanya berlaku selama 2 (dua) tahun, dan sesudah 2 (dua) tahun diadakan pembaruan. Selama peraturan perusahaan masih berlaku, perusahaan dapat mengadakan perubahan isi peraturan perusahaan 
setelah mendapat persetujuan dari pekerja/serikat pekerja. ${ }^{1}$

Pengusaha yang mempekerjakan pekerja/buruh sekurang-kurangnya 10 (sepuluh) orang wajib membuat peraturan perusahaan, yaitu peraturan yang dibuat secara tertulis oleh pengusaha yang memuat syarat-syarat keria dan tata tertib perusahaan. Pembuatan peraturan perusahaan merupakan tanggung jawab pengusaha yang dalam proses pembuatannya harus memperhatikan saran dan pertimbangan dari wakil pekeria buruh atau dari serikat pekerja/ buruh apabila di perusahaan telah terbentuk serikat pekerja/buruh. ${ }^{2}$ Peraturan perusahaan pedoman bagi kedua belah pihak dalam melaksanakan hubungan kerja artinya dengan mengetahui hak dan kewajibannya dalam hubungan kerja dapat dihindari terjadinya perbedaan persepsi tentang hak dan kewajiban antara para pihak (pekerja/buruh dan pengusaha) dalam hubungan kerja dan bila teriadi perbedaan dapat melihat kembali peraturan perusahaan sebagai pedoman.

Dengan adanya pengaturan yang jelas dan tertulis dalam peraturan perusahaan diharapkan akan terciptanya ketenangan bekerja, peningkatan produktivitas kerja, keuntungan dan kelangsungan usaha dan akhirnya pengusaha dapat memberikan upah yang lebih baik, jaminan sosial, serta fasilitas

Modul Lembaga Peraturan Perusahaan, (2013), Diklat Mediator Hubungan Industrial, Kementerian Tenagakerja dan Transmigrasi Republik Indonesia, Sekretariat Jendral, Pusat Pendidikan dan Pelatihan Pegawai, hlm. i.

Modul Lembaga Peraturan Perusahaan, (2013), Diklat... Ibid, hlm. 1 kesejahteraan kepada pekerja dan keluarganya. ${ }^{3}$

Peraturan perusahaan yang diteliti oleh Penulis banyak yang tidak sama dalam sistematikanya, bahasa atau kalimatnya tidak jelas, hak dan kewajiban pekerja dan pengusaha belum ditulis secara rinci. Berdasarkan uraian di atas, Penulis melakukan kegiatan pengabdian kepada masyarakat mengenai "TATA CARA MEMBUAT PERATURAN PERUSAHAAN".

Adapun hal-hal yang dilakukan dalam kegiatan pengabdian pada masyarakat ini meliputi: Materimateri apa saja yang disampaikan dalam penyuluhan tentang pembuatan peraturan perusahaan? Bagaimana respon dari pekerja dan pengusaha mengenai kegiatan penyuluhan tentang pembuatan peraturan perusahaan?

\section{Lokasi Pengabdian}

Pengabdian dilaksanakan di PT. Pelangi Warna Kreasi, yang beralamat di Jalan Cibolerang No. 145 A (Komplek industri Bandung40225), pada tanggal 12 Juli 2016.

\section{Peserta}

Adapun jumlah peserta sebanyak 20 (dua puluh) orang baik dari pekerja maupun pihak pengusaha.

\section{B. METODE}

Dalam hal ini, penulis menggunakan metode penelitian deskriptif kualitatif yaitu metode dalam penelitian suatu obyek, suatu peristiwa pada masa sekarang. Unit analisis data dalam penelitian ini meliputi karyawan PT. Pelangi Warna Kreasi beserta

Modul Lembaga Peraturan Perusahaan, (2013), Diklat... Ibid, hlm. 2. 
pengusaha. $^{4}$ Jenis data yang digunakan dalam penelitian ini berasal dari dua sumber, yaitu: Data primer merupakan keseluruhan data hasil penelitian yang diperoleh melalui wawancara dengan pimpinan perusahaan dan beberapa pengusaha. Data sekunder merupakan data yang diperoleh dari instansi terkait dan studi dokumentasi serta literatur-literatur, terutama yang berkaitan dengan masalah penelitian ini. Dalam penelitian ini, metode analisis data yang digunakan adalah model analisis interaksi yaitu reduksi data dengan mekanisme data yang terkumpul dipilih dan dikelompokkan berdasarkan data yang sama. Data tersebut kemudian diorganisasikan untuk mendapatkan kesimpulan sebagai bahan penyaji data. Setelah data diorganisasikan, selanjutnya data disajikan dalam uraian-uraian naratif yang disertai dengan bagan atau tabel untuk memperielas penyajian data. 5

\section{HASIL/PEMBAHASAN}

1. Pembuatan Perusahaan

Peraturan

Berdasarkan Pasal 3 UndangUndang Nomor 13 Tahun 2003 menegaskan bahwa pembangunan ketenagakerjaan diselenggarakan atas asas keterpaduan melalui koordinasi fungsional lintas sektoral pusat dan daerah. Asas pembangunan ketenagakerjaan pada dasarnya sesuai dengan asas pembangunan nasional, khususnya asas demokrasi, asas adil, dan

Haris Herdiansyah, (2010), Metode penelitian kualitatif. Jakarta, Selemba Humanika, hlm. 25.

Bagong Suyanto dan Sutimah, (2010), Metode Penelitian Sosial: Sebagai Alternative Pendekatan, Jakarta, Kencana, hlm. 87-93. merata. Hal ini dilakukan karena pembangunan ketenagakerjaan menyangkut multidimensi dan terkait dengan berbagai pihak, yaitu antara pemerintah, pengusaha, dan pekerja/buruh. Oleh karena itu, pembangunan ketenagakerjaan dilakukan secara terpadu dalam bentuk kerjasama yang saling mendukung. ${ }^{6}$ Jadi asas Hukum Ketenagakerjaan adalah asas keterpaduan melalui koordinasi fungsional lintas sektoral pusat dan daerah.

Tujuan Hukum Ketenagakerjaan ialah:

a. Untuk mencapai/melaksanakan keadilan sosial dalam bidang ketenagakerjaan.

b. Untuk melindungi tenaga kerja terhadap kekuasaan yang tidak terbatas dari pengusaha.

Butir (a) lebih menunjukkan bahwa Hukum Ketenagakerjaan harus menjaga ketertiban, keamanan dan keadilan bagi pihak-pihak yang terkait dalam proses produksi, untuk dapat mencapai ketenangan bekerja dan kelangsungan berusaha, sedangkan butir (b) dilatarbelakangi adanya pengalaman selama ini yang sering terjadi kesewenang-wenangan pengusaha terhadap pekerja/buruh, untuk itu diperlukan suatu perlindungan hukum secara komprehensif dan konkret dari pemerintah.

Berdasarkan Pasal 4 UndangUndang Nomor 13 Tahun 2003 bahwa pembangunan ketenagakerjaan bertujuan:

a. Memberdayakan dan mendayagunakan tenaga kerja secara optimal dan manusiawi.

\footnotetext{
Bagus Prasetyo, (2014), Menilik Kesiapan Dunia Ketenagakerjaan Indonesia Menghadapi MEA, Jurnal Rechts Vinding Media Pembinaan Hukum Nasional, hlm. 3-4.
} 
b. Mewujudkan kesempatan kerja dan penyediaan tenaga keria yang sesuai dengan kebutuhan pembangunan nasional dan daerah.

c. Memberikan perlindungan kepada tenaga kerja dalam mewujudkan kesejahteraan, dan

d. Meningkatkan kesejahteraan tenaga kerja dan keluarganya. ${ }^{7}$

Dalam Pasal 1 angka 2 UndangUndang Nomor 13 Tahun 2003 Tentang Ketenagakerjaan, istilah tenaga kerja mengandung pengertian yang bersifat umum, yaitu setiap orang yang mampu melakukan pekerjaan guna menghasilkan barang dan/atau jasa untuk memenuhi kebutuhan sendiri maupun untuk masyarakat.

Menurut Pasal 1 angka 3 UndangUndang Nomor 3 Tahun 1992 Tentang Jaminan Sosial Tenaga Kerja dan Pasal 1 angka 5 UndangUndang Nomor 13 Tahun 2003 Tentang Ketenagakerjaan.

Selanjutnya, pelaksanaan dalam proses produksi barang dan jasa sedikitnya terdapat 2 (dua) pihak yang terkait yaitu pengusaha dan pekerja di perusahaan, untuk menjamin berjalannya proses produksi tersebut diperlukan adanya pengaturan hak dan kewajiban bagi kedua belah pihak. Hak dan kewajiban pekerja dan pengusaha secara umum telah diatur dalam peraturan perundang-undangan sebagai norma keria yang harus dipatuhi oleh semua perusahaan tanpa melihat besar kecilnya perusahaan, dan dapat dikenai sanksi, misal kewajiban perusahaan

Payaman J. Simanjuntak, (2003), UndangUndang yang Baru tentang Ketenagakerjaan, Jakarta, Kantor Perburuhan Internasional, hlm. 11-12. untuk mengikutsertakan para pekerjanya menjadi peserta program Jamsostek, kalau perusahaan tidak mengikutsertakan dapat dikenai sanksi. Namun dalam praktik, masih banyak hak dan kewajiban yang diperlukan dalam hubungan kerja tetapi belum diatur dalam peraturan perundangundangan, misalnya tata tertib, ketentuan disiplin kerja yang berkaitan dengan pakaian seragam, jam masuk dan pulang kerja, pengambilan hak cuti dan sebagainya. Oleh karena itu, perlu pengaturan sendiri di masing-masing perusahaan syarat-syarat kerja. ${ }^{8}$

Pengaturan mengenai syarat kerja dan tata tertib tersebut sesuai dengan Undang-Undang Nomor 13 Tahun 2003, Tentang Ketenagakerjaan yang dapat dituangkan dalam Perjanjian Kerja (PK), peraturan perusahaan (PP) atau Perianiian Kerja Bersama (PKB). Pengaturan syarat-syarat kerja melalui pembuatan peraturan perusahaan sangat strategis karena diwajibkan kepada semua perusahaan yang mempekerjakan tenaga kerja 10 (sepuluh) orang atau lebih, karena dengan pengaturan seperti itu sebagian besar perusahaan wajib membuat peraturan perusahaan, sehingga pekerja telah mendapat kejelasan dan kepastian tentang hak dan kewajibanya dalam hubungan keria. ${ }^{9}$ Hubungan kerja adalah hubungan antara pekerja dengan pengusaha yang terjadi setelah adanya perjanjian kerja. Di dalam Pasal 1 angka 15 Undang-Undang Nomor 13 Tahun 2003 dijelaskan bahwa: 


"Hubungan kerja adalah
hubungan antara pengusaha
dengan pekerja/buruh
berdasarkan perjanjian kerja
yang mempunyai unsur
pekerjaan, upah, dan
perintah".

Dengan demikian jelaslah bahwa hubungan kerja terjadi karena adanya perjanjian kerja antara pengusaha dan pekerja/buruh.

Dari pengertian tersebut jelaslah bahwa hubungan keria sebagai bentuk hubungan hukum, lahir atau tercipta setelah adanya perjanjian keria antara pekerja dengan pengusaha. Substansi perianiian kerja yang dibuat tidak boleh bertentangan dengan perianiian perburuhan atau Kesepakatan Kerja Bersama (KKB)/Perjanjian Kerja Bersama (PKB) yang ada, demikian halnya dengan peraturan perusahaan, subtansinya tidak boleh bertentangan dengan KKB/PKB.

Berdasarkan Pasal 1 angka 20 Undang-Undang Nomor 13 Tahun 2003, Peraturan Perusahaan (PP) ialah peraturan yang dibuat secara tertulis oleh pengusaha yang memuat syarat-syarat keria dan tata tertib perusahaan.
a. Sasaran Pembuatan Peraturan Perusahaan.
b. Manfaat Pembuatan Peraturan Perusahaan. ${ }^{10}$
c. Fungsi Pembuatan Peraturan Perusahaan.
d. Tujuan Pembuatan Peraturan Perusahaan. ${ }^{11}$
e. Persyaratan Pembuatan Peraturan Perusahaan. ${ }^{12}$

10 Daniri Mas Ahmad, (2005), Good Corporate Governance: Konsep dan Penerapannya di Indonesia, Jakarta, Ray Indonesia, hlm. 27-28.

11 Moeljono Djokosantoso, (2005), Good Corporate Culture sebagai inti dari Good Corporate Governance, Jakarta, Elex-Gramedia, hlm. 4244. f. Materi Yang Diatur Dalam Peraturan Perusahaan.

g. Sistematika

Peraturan Perusahaan.

Masa Berlaku peraturan perusahaan adalah paling lama 2 (dua) tahun dan wajib diperbaiki setelah habis masa berlakunya. Adapun tata cara pembuatan peraturan perusahaan adalah sebagai berikut:
a. Pembuatan
Peraturan
Perusahaan Baru.
b. Perubahan
Perusahaan.
c. Pembaharuan
Perusahaan. ${ }^{13}$

Selanjutnya proses mendapatkan persetujuan dari wakil pekerja/buruh adalah:

a. Pengusaha menyerahkan naskah rancangan peraturan perusahaan kepada perwakilan pekerja/buruh untuk mendapatkan saran dan pertimbangan.

b. Saran dan pertimbangan harus sudah diterima pengusaha kembali dalam waktu 14 hari kerja sejak diterimanya naskah rancangan peraturan perusahaan

c. Dalam waktu 14 hari kerja, tidak memberikan saran dan pertimbangan, pengusaha dapat mengajukan permohonan pengesahan peraturan perusahaan disertai bukti bahwa rancangan peraturan perusahaan tersebut telah diserahkan kepada wakil pekerja/buruh tetapi sampai batas waktu yang ditentukan wakil pekeria tidak memberikan saran dan pertimbangan.

\footnotetext{
12 Shaw, John. C, (2003), Corporate Governance and Risk: A System Approach, New Jersey: John Wiley \& Sons, Inc, hlm. 134-137.

13 Aburizal Bakrie, (2002), Good Corporate Governance: Sudut Pandang Pengusaha, Jakarta, YPMMI \& Sinergi Communication, 84-86.
} 
Peraturan perusahaan harus disahkan oleh dinas yang bertanggung jawab di bidang ketenagakerjaan. Adapun tujuan pengesahan adalah:

a. Mencegah agar materi yang diatur dalam peraturan perusahaan tidak bertentangan dengan peraturan perundangundangan yang berlaku.

b. Meningkatkan kualitas syaratsyarat kerja yang diatur dalam peraturan perusahaan.

Persyaratan

Permohonan

Pengesahan:

a. Mengajukan permohonan pengesahan peraturan perusahaan secara tertulis kepada menteri atau pejabat yang ditunjuk.

b. Melampirkan naskah peraturan perusahaan rangkap 3 yang telah ditandatangani oleh pengusaha.

c. Melampirkan bukti telah diminta saran dan pertimbangan dari perwakilan pekerja/buruh (bukti tersebut berupa tanda terima penyerahan naskah, atau pernyataan dari wakil pekerja).

Surat permohonan pengesahan peraturan perusahaan memuat:

a. Nama dan alamat perusahaan.

b. Nama pimpinan perusahaan.

c. Wilayah operasi perusahaan.

d. Status perusahaan.

e. Jenis atau bidang usaha.

f. Jumlah pekerja menurut jenis kelamin.

g. Status hubungan kerja.

h. Upah tertinggi dan terendah.

i. Nama dan alamat sp/sb bila ada.

j. Masa berlaku.

k. Pengesahan peraturan perusahaan yang ke berapa.

Proses Pengesahan peraturan perusahaan adalah sebagai berikut: a. Meneliti kelengkapan dokumentasi dan materi peraturan perusahaan.

b. Perusahaan wajib menyampaikan naskah peraturan perusahaan dalam waktu paling lama 14 (empat belas) hari kerja sejak tanggal diterimanya pengembalian peraturan perusahaan.

c. Apabila tidak dikembalikan dalam waktu paling lama 14 (empat belas) hari keria, dapat dianggap perusahaan belum memiliki peraturan perusahaan.

d. Menteri atau pejabat yang ditunjuk wajib menerbitkan surat keputusan pengesahan peraturan perusahaan, dalam waktu paling lama 30 (tiga puluh) hari kerja.

e. Dalam waktu 30 (tiga puluh) hari kerja telah terlampaui dan peraturan perusahaan telah memenuhi syarat, menteri atau pejabat yang ditunjuk belum menerbitkan surat keputusan pengesahan maka peraturan perusahaan dianggap telah mendapatkan pengesahan.

Instansi yang berwenang mengesahkan peraturan perusahaan:

a. Direktur Jenderal Pembinaan Hubungan Industrial untuk perusahaan yang terdapat di lebih dari satu provinsi.

b. Dinas yang bertanggung jawab di bidang ketenagakerjaan tingkat provinsi untuk perusahaan yang terdapat pada lebih dari satu Kabupaten/Kota dalam 1 (satu) provinsi.

c. Dinas yang bertanggung jawab di bidang ketenagakerjaan tingkat Kab./Kota untuk perusahaan yang terdapat hanya dalam 1 (satu) Kab./ Kota. 
$\mathrm{Di}$ dalam peraturan perusahaan ditentukan hak dan kewajiban pekerja dan pengusaha yang meliputi:

a. Kewajiban Pengusaha.

1) Memberitahukan dan menjelaskan isi peraturan perusahaan kepada semua pekerja.

2) Membagikan buku peraturan perusahaan kepada semua pekerja.

3) Melaksanakan isi peraturan perusahaan dengan penuh tanggung jawab.

b. Kewajiban pekerja/buruh.

1) Membaca dan memahami isi peraturan perusahaan.

2) Melaksanakan isi peraturan perusahaan dengan penuh tanggung jawab.

Di dalam pemberlakuan peraturan perusahaan tersebut perlu dilakukan pengawasan.

Pengawasan ketenagakerjaan dilaksanakan untuk menjamin pelaksanaan peraturan ketenagakerjaan. Ruang lingkup pengawasan ketenagakerjaan meliputi:

a. Mengawasi;

b. Mengumpulkan bahan-bahan;

c. menjalankan pekerjaan lain sesuai undang-undang.

Ketiga tugas tersebut

dilaksanakan oleh Menteri Tenaga

Kerja dengan menunjuk Pegawai

Pengawas, yang memiliki kewajiban

dan wewenang penuh dalam melaksanakan fungsi pengawasan dengan baik.

Pelaksanaan pengawasan ketenagakerjaan dilakukan oleh unit kerja tersendiri pada instansi yang bertanggung jawab di bidang ketenagakerjaan. Dalam melaksanakan tugasnya Pegawai Pengawas berhak dan wajib melakukan:

a. Memasuki semua tempat di mana dijalankan atau biasa dijalankan pekerjaan atau dapat disangka bahwa di situ dijalankan pekerjaan, dan juga segala rumah yang disewakan atau dipergunakan oleh pengusaha atau wakilnya untuk perumahan atau perawatan pekerja.

b. Jika terjadi penolakan untuk memasuki tempat-tempat tersebut, pegawai pengawas berhak meminta bantuan polisi.

c. Mendapatkan keterangan sejelas-jelasnya dari pengusaha atau wakilnya dan pekerja/ buruh mengenai kondisi hubungan kerja pada perusahaan yang bersangkutan.

d. Menanyai pekerja tanpa dihadiri pihak ketiga.

e. Harus melakukan koordinasi dengan serikat pekerja.

f. Wajib merahasiakan segala keterangan yang didapat dari pemeriksaan tersebut.

g. Wajib mengusut pelanggaran. ${ }^{14}$

\section{Respon Peserta terhadap Kegiatan Penyuluhan Tentang Tata Cara Pembuatan Peraturan Perusahaan}

Proses sosial merupakan suatu proses yang berarti suatu gejala perubahan, gejala penyesuaian diri, gejala pembentukan. Phil Astrid berpendapat bahwa semua gejala ini disebabkan karena individuindividu dalam kelompok menyesuaikan diri satu sama lain, menyesuaikan diri dengan keadaan. Usaha ini akan terus menerus dilakukannya selama kelompok itu bernilai baginya, selama dirasakannya bahwa perusahaan memerlukan kelompok untuk kemajuan dan perkembangan dirinya. Karena itu,

14 Payaman J. Simanjuntak, (2003), Undang-

Undan ... Op Cit, hlm. 18. 
proses ini menjurus menjadi proses sosialisasi. ${ }^{15}$

Selanjutnya, Charlotte Buehler mengatakan bahwa sosialisasi ialah proses yang membantu individu melalui belajar dan menyesuaikan diri, bagaimana cara hidup dan bagaimana cara berpikir kelompoknya, agar supaya dapat berperan dan berfungsi dalam kelompoknya. ${ }^{16}$ Proses ini dapat berjalan dengan serasi, dapat pula terjadi melalui pertentangan akan tetapi selama individu merasa memerlukan kelompoknya, maka ia bersedia untuk mengadakan beberapa kompromi terhadap tuntutan kelompok. Proses sosialisasi ini terjadi melalui interaksi sosial yaitu hubungan antar manusia yang menghasilkan suatu proses pengaruh mempengaruhi. Dalam proses pendewasaan manusia berdasarkan pengalamannya sendiri selalu akan terbentuk suatu sistem perilaku (behavior system) yang juga ikut ditentukan oleh watak pribadinya, yaitu bagaimana pimpinan akan memberi reaksi terhadap suatu pengalaman. Akhirnya sistem perilaku inilah yang akan menentukan dan membentuk sikapnya terhadap sesuatu. ${ }^{17}$

Sosialisasi Undang-Undang Nomor 13 Tahun 2003 penting dilaksanakan secara kontinyu, salah satu materi dalam ketenagakerjaan adalah mengenai peraturan perusahaan. Kehadiran Undang-Undang Nomor 13 Tahun 2003 tentang Ketenaga-

15 Phil Astrid, Pengantar Sosiologi dan Perubahan Sosial, cetakan pertama, Penerbit Bina Cipta, Anggota IKAPI, 1983, hlm 12.

16 Charlotte Buehler, Psychology for contemporary living, terjemahan ke dalam bahasa Inggris, a delta booki, Dell Publishing Co.Inc. New York, hlm 172.

17 Charlotte Buehler, Psychology for.... Ibid, hlm 173. kerjaan telah memberikan nuansa baru dalam khasanah hukum ketenagakerjaan yakni:

a. Mensejajarkan istilah buruh/ pekerja, istilah majikan diganti menjadi pengusaha dan pemberi kerja.

b. Menggantikan istilah perjanjian perburuhan (labour agreement)/ Kesepakatan Keria bersama (KKB) dengan istilah Perjanjian Kerja Bersama (PKB), dengan alasan bahwa perjanjian perburuhan berasal dari negara liberal yang seringkali dalam pembuatannya menimbulkan benturan kepentingan antara pihak buruh dengan majikan.

c. Sesuai dengan perkembangan zaman memberikan kesetaraan antara pekerja pria dan wanita, khususnya untuk bekerja pada malam hari. Pengusaha diberikan rambu-rambu yang harus ditaati mengenai hal ini.

d. Memberikan sanksi yang memadai serta menggunakan batasan minimum dan maksimum, sehingga lebih menjamin kepastian hukum dalam penegakannya.

e. Mengatur mengenai sanksi administratif mulai dari teguran, peringatan tertulis, pembatasan kegiatan usaha, pembekuan kegiatan usaha, pembatalan persetujuan, pembatalan pendaftaran, penghentian sementara sebagian atau seluruh alat produksi dan pencabutan izin. Pada peraturan perundangundangan sebelumnya sanksi ini tidak diatur.

Hukum Ketenagakerjaan memiliki unsur-unsur:

a. Serangkaian peraturan yang terbentuk tertulis dan tidak tertulis. 
b. Mengatur tentang kejadian hubungan kerja antara pekeria dan pengusaha/majikan.

c. Adanya orang bekerja pada dan di bawah orang lain, dengan mendapat upah sebagai balas jasa.

d. Mengatur perlindungan pekeria/ buruh, meliputi masalah keadaan sakit, haid, hamil, melahirkan, keberadaan organisasi pekeria/buruh dan sebagainya.

Salah satu bentuk perlindungan yang diberikan oleh pengusaha adalah isi dari peraturan perusahaan yang berpihak pada pekeria yang sesuai peraturan perundang-undangan yang berlaku. Lingkup perlindungan terhadap pekeria/buruh menurut Undang-Undang Nomor 13 Tahun 2003 meliputi:

a. Perlindungan atas hak-hak dasar pekerja/buruh untuk berunding dengan pengusaha.

b. Perlindungan keselamatan dan kesehatan kerja.

c. Perlindungan khusus bagi pekerja/buruh perempuan, anak dan penyandang cacat, dan

d. Perlindungan tentang upah, kesejahteraan, dan jaminan sosial tenaga kerja.

\section{PENUTUP}

Merujuk ke dalam Undang-Undang Nomor 13 Tahun 2003 tentang Ketenagakerjaan, maka Penulis melakukan kegiatan pengabdian kepada masyarakat yaitu penyuluhan tentang cara membuat peraturan perusahaan yang dilakukan oleh penulis disambut baik oleh pengusaha dan pekerja/serikat pekerja. Hal ini dapat dilihat dari berbagai macam pertanyaan dalam sesi tanya jawab, bahkan ada kegiatan selanjutnya yang diminta oleh perusahaan terkait ketenagakerjaan.

\section{UCAPAN TERIMA KASIH}

Terima kasih atas kerja samanya dengan Direktur PT. Pelangi Warna Kreasi.

\section{DAFTAR PUSTAKA}

\section{A. Buku}

Abdul Khakim, (2003), Pengantar Hukum Ketenagakerjaan Indonesia Berdasarkan UU No. 13 Tahun 2003, Bandung, Citra Aditya Bakti.

Aburizal Bakrie, (2002), Good Corporate Governance: Sudut Pandang Pengusaha, Jakarta: YPMMI \& Sinergi Communication.

Bagong Suyanto dan Sutimah, (2010), Metode Penelitian Sosial: Sebagai Alternative Pendekatan, Jakarta: Kencana.

Charlotte Buehler, Psychology for contemporary living, a delta booki, terjemahan ke dalam bahasa Inggris Dell Publishing Co.Inc. New York. Tt.

Haris Herdiansyah, (2010), Metode penelitian kualitatif. Jakarta: Selemba Humanika.

Mas Ahmad, Daniri, (2005), Good Corporate Governance: Konsep dan Penerapannya di Indonesia, Jakarta, Ray Indonesia.

Moeljono Diokosantoso, (2005), Good Corporate Culture sebagai inti dari Good Corporate Governance, Jakarta, ElexGramedia.

Payaman, J. Simanjuntak, (2003), Undang-Undang yang Baru tentang Ketenagakerjaan, 
Jakarta, Kantor Perburuhan Internasional.

Phil Astrid, (1983), Pengantar Sosiologi dan Perubahan Sosial, cetakan pertama, Tanggerang, Bina Cipta, Anggota IKAPI.

Shaw, John. C, (2003), Corporate Governance and Risk: A System Approach, New Jersey: John Wiley \& Sons, Inc.

\section{B. Peraturan \\ Perundang- undangan}

Undang-Undang Dasar 1945.

Undang-Undang Nomor 3 Tahun 1992 tentang Jaminan Sosial Tenaga Kerja.

Undang-Undang Nomor 13 Tahun 2003 tentang Ketenagakerjan.
C. Jurnal

Prasetyo, Bagus, (2014), Menilik Kesiapan Dunia Ketenagakerjaan Indonesia Menghadapi MEA, Jurnal Rechts Vinding Media Pembinaan Hukum Nasional.

\section{Modul}

Modul Lembaga Peraturan Perusahaan, (2013), Diklat Mediator Hubungan Industrial, Kementerian Tenagakerja dan Transmigrasi Republik Indonesia, Sekretariat Jendral, Pusat Pendidikan dan Pelatihan Pegawai. 